\title{
Does Evidence Really Matter?
}

\author{
Kevin W Hall
}

W

hen I was in my mid-40s, I took up golf and quickly realized that it is a challenging game. More than 10 years later, after many games of golf and several visits to golf schools, I still consider it a good day if I break 100 over the course of 18 holes. My only consolation is that I am not alone: according to a few golf books that I have read, fewer than $10 \%$ of those who golf will ever legitimately score less than 100 . I was therefore a little skeptical when, after the recent death of Kim Jong Il, the "Great Leader" of North Korea, I read of the miraculous accomplishments with which he was credited, including the claim that in his first game of golf he shot almost a dozen consecutive holes-in-one. ${ }^{1}$

Many of Kim Jong Il's other miraculous accomplishments seem similarly implausible. In fact, many of you may be wondering, as I have, whether anyone in North Korea really takes those claims seriously. In an article that appeared in the Globe and Mail' shortly after Christmas 2011, Canadian North Korea watcher and former Pyongyang resident Erich Weingartner was quoted as saying, "There's still a lot of people who regard at least Kim Il-sung [the first of the 3 Kim family rulers and father of Kim Jong-il] as a god figure". When asked to comment, Professor Paul Evans, director of the Institute of Asian Research at the University of British Columbia, cautioned that we should be careful not to conclude that people in North Korea are any more prone to believe the implausible than the rest of us. After all, he pointed out, North Americans had just gone through the Christmas season, when Christians accept as truth the story of a virgin birth, angels descending from the sky, and a star moving through the night sky to lead the Three Kings to their destination.

What does all of this have to do with pharmacy? To begin with, belief is an extremely important human attribute. Not everything can be proven or disproven. We may believe that someone loves us, but can science really prove or disprove that belief? Should we abandon our belief in love on the basis that it cannot be scientifically proven? On the other hand, when a question can be subjected to scientific inquiry, what obligation do we, as professionals, have when beliefs and science collide?
Pharmacy faces a number of issues where a good argument can be made that we, as a profession, are failing to address inconsistencies between the available evidence and our own response to that evidence.

Complementary and alternative medicine is one such area. In his book Snake Oil Medicine: The

Truth About Complementary and Alternative Medicine, ${ }^{2}$ Bausell makes the case that, with few exceptions, most complementary and alternative therapy, in and of itself, has no beneficial effect. That is not to say that patients don't experience what they perceive to be beneficial effects, but rather that the beneficial effects can be largely, if not entirely, attributed to a family of psychological and physiological effects that collectively constitute what is known as the placebo effect. Despite the evidence to that effect that has accumulated in recent years, Bausell himself acknowledges that if current trends continue, most North Americans, at least those who can afford it, will soon be engaging in complementary and alternative medicine practices. In recognition of this non-evidence-based reality, many community pharmacies are expanding their complementary and alternative therapy offerings, faculties of pharmacy are introducing courses in this area, and community colleges are offering certification programs in various practice areas within complementary and alternative medicine. In fact, complementary and alternative medicine has reached the point where it is considered a sign of closed-mindedness to question the merits of its therapies, therapies for which there is rarely the type of scientific evidence required for traditional medicines. Some may argue that complementary and alternative medicine is, at worst, harmless, but that is not always the case. Serious adverse effects do occur. ${ }^{3,4}$ In addition, is it appropriate to ignore the fact that large sums of money are being spent on products with little or no evidence to support their purported benefits? 
Looking at evidence from another perspective, we can ask how pharmacy practitioners respond when there is a reasonably robust body of evidence available to inform our decisions. The most recent 3 Hospital Pharmacy in Canada Reports have each included a section examining the relationship between how pharmacy departments prioritize various pharmacy activities and the evidence supporting the value of those activities. The results suggest a significant disconnect between the evidence and how pharmacy activities are prioritized. ${ }^{5}$

Another area where evidence exists but adoption is painstakingly slow involves the uptake of new professional roles that have been demonstrated to improve patient outcomes. ${ }^{6-9}$ Canadians are not experiencing the full benefits of pharmacist care because of the profession's slow and seemingly reluctant adoption of an expanded scope of practice, a new direction that is clearly supported by scientific evidence.

In their 2009 book Unscientific America: How Scientific Illiteracy Threatens our Future, ${ }^{10}$ Mooney and Kirshenbaum raised the alarm about the disregard for scientific evidence that is becoming prevalent in our modern society. Maybe we should ask ourselves if, in all honesty, evidence really does matter in the practice of pharmacy. Do we really use evidence to make decisions about what we should and should not be doing as a profession? At a personal level, each of us can ask the same types of questions: Is my day-to-day practice evidence-based or preference-based? Am I prepared to focus my practice on activities that have been demonstrated to improve patient outcomes, such as medication reconciliation? Do I support the establishment of evidence-based practice expectations and accountability, or do I dismiss that as a "cookie-cutter" approach to pharmacy practice?

In closing, I have a confession to make: I'm still expecting to tee off at the Masters Golf Tournament sometime soon, despite all the evidence to the contrary that has accumulated over these past 10 years!

\section{References}

1. Reeder M. Sifting through the golf sands for a hint of North Korea's future. Globe and Mail [Toronto, ON]: 2011 Dec 30 [cited 2012 Feb
28]. Available from: http://vtncankor.wordpress.com/2012/01/05/ sifting-through-the-golf-sands-for-a-hint-of-north-koreas-future/

2. Bausell RB. Snake oil science: the truth about complementary and alternative medicine. New York (NY): Oxford University Press; 2007.

3. Niggemann B, Grüber C. Side-effects of complementary and alternative medicine. Allergy 2003;58(8):707-716.

4. Ernst E. Heavy metals in traditional Indian remedies. Eur J Clin Pharmacol 2002;57(12):891-896.

5. Bussières JF. Clinical pharmacy services. In: Babich M, Bornstein C, Bussières JF, Hall K, Harding J, Lefebvre P, et al., editors. Hospital pharmacy in Canada 2009/2010 report. Eli Lilly; 2010 [cited 2012 Feb 28]. p. 3-20. Available from: www.lillyhospitalsurvey.ca/hpc2/content/2010_report/ chapter_b\%20.pdf

6. Tsuyuki RT, Johnson JA, Teo KK, Simpson SH, Ackman ML, Biggs RS, et al. A randomized trial of the effect of community pharmacist intervention on cholesterol risk management: the Study of Cardiovascular Risk Intervention by Pharmacists (SCRIP). Arch Intern Med 2002;162(10):11491155.

7. McLean DL, McAlister FA, Johnson JA, King KM, Makowsky MJ, Jones $\mathrm{CA}$, et al. A randomized trial of the effect of community pharmacist and nurse care on improving blood pressure management in patients with diabetes mellitus: study of cardiovascular risk intervention by pharmacistshypertension (SCRIP-HTN). Arch Intern Med 2008;168(21):2355-2361.

8. Chabot I, Moisan J, Grégoire JP, Milot A. Pharmacist intervention program for control of hypertension. Ann Pharmacother 2003;37(9): 1186-1193.

9. Koshman SL, Charrois TL, Simpson SH, McAlister FA, Tsuyuki RT. Pharmacist care of patients with heart failure: a systematic review of randomized trials. Arch Intern Med 2008;168(7):687-694.

10. Mooney C, Kirshenbaum S. Unscientific America: how scientific illiteracy threatens our future. New York (NY): Basic Books, A Member of the Perseus Books Group; 2009.

Kevin W Hall, BScPharm, PharmD, FCSHP, is a Clinical Associate Professor with the Faculty of Pharmacy and Pharmaceutical Sciences at the University of Alberta, Edmonton, Alberta. He is also an Associate Editor with the CJHP.

Address correspondence to:

Dr Kevin W Hall

Faculty of Pharmacy and Pharmaceutical Sciences

University of Alberta

ECHA 3-228

Edmonton AB T6G 1C9

e-mail: khall@pharmacy.ualberta.ca

\section{ON THE FRONT COVER}

\section{Gros Morne, Newfoundland and Labrador}

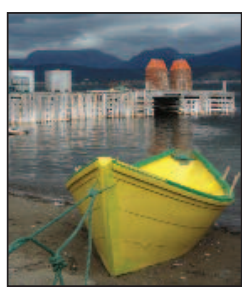

CSHP member Heather Foley took this photograph after enjoying a delicious home-cooked lunch at the Old Loft Restaurant in Woody Point, Newfoundland and Labrador. The yellow boat gleamed like a bright sun on an overcast September day, providing dramatic contrast to the majestic view of Gros
Morne Mountain. Heather used a Nikon D60 camera for this image. Heather is currently a pharmacy resident at Hôtel-Dieu Grace Hospital in Windsor, Ontario.

The CJHP would be pleased to consider photographs featuring Canadian scenery taken by CSHP members for use on the front cover of the journal. If you would like to submit a photograph, please send an electronic copy (minimum resolution $300 \mathrm{dpi}$ ) to Colleen Drake at cdrake@cshp.ca. 